\title{
Root system characteristics of Marandu palisadegrass supplied with nitrogen and magnesium rates
}

\author{
Tiago Barreto Garcez ${ }^{1}$, Marcio Mahmoud Megda², Adriana Guirado Artur², \\ Francisco Antonio Monteiro ${ }^{3}$
}

\footnotetext{
1 Universidade de São Paulo, Escola Superior de Agricultura "Luiz de Queiroz", Pós-Graduação em Solos e Nutrição de Plantas. Bolsista CAPES.

2 Universidade de São Paulo, Escola Superior de Agricultura "Luiz de Queiroz", Pós-Graduação em Solos e Nutrição de Plantas. Bolsista CNPq.

${ }^{3}$ Universidade de São Paulo, Escola Superior de Agricultura "Luiz de Queiroz", Departamento de Ciência do Solo, Piracicaba-SP-Brasil. Bolsista CNPq.
}

ABSTRACT - The development of root system of forage grasses is influenced by the supply of mineral nutrients. The experiment was carried out in a greenhouse in Piracicaba, São Paulo State, with the objective of evaluating the effect of nitrogen and magnesium rates on dry mass yield, total length and surface, specific length and surface, and concentrations of nitrogen, magnesium, calcium and potassium in the root system of Brachiaria brizantha Stapf. cv. Marandu. It was studied five rates of nitrogen $\left(2,9,16,23\right.$ and $\left.30 \mathrm{mmol} \mathrm{L}^{-1}\right)$ and five rates of magnesium $\left(0.05,0.70,1.35,2.00\right.$ and $\left.2.65 \mathrm{mmol} \mathrm{L}^{-1}\right)$ in nutrient solutions in an incomplete $5^{2}$ factorial arrangement, which resulted in the following combinations: 2/0.05; 2/1.35; 2/2.65; 9/0.70; 9/2.00; 16/0.05; 16/1.35; 16/2.65; 23/0.70; 23/2.00; 30/0.05; 30/1.35 and 30/2.65. The experimental design was a randomized block with four replications. Plants had two growth periods, and after the second harvest the roots were separated from the plant tops. Combination of the high rates of nitrogen and magnesium resulted in expressive increases in rooty dry matter yield, in the length and in the root surface of marandu palisadegrass. High rates of nitrogen and magnesium resulted in short root specific length and surface. Combinations of high rates of nitrogen and magnesium increased nitrogen concentration or decreased potassium concentration in the roots. Calcium concentration in the roots was increased by nitrogen rates and decreased by magnesium rates. Magnesium rates resulted in increase in magnesium concentration in the roots of marandu palisadegrass.

Key Words: Brachiaria brizantha, nutrient, nutrient solution, root, root length, root surface

\section{Introduction}

Pasture lands in Brazil extends for approximately 172 millions of hectares, an area expressively greater than that cultivated with grains (approximately 77 millions of hectares) (IBGE, 2006). Most of this pasture land is cultivated with grasses of genus Brachiaria. In recent years, Brachiaria brizantha cv. Marandu is being preferentially cultivated instead of Brachiaria decumbens, due to greater productivity of the former one.

In general, studies on root characteristics of forage grasses is scarce. The root system supplies water and nutrients to the above ground portion of plants, which in turn send photosynthates and growth regulators back to the roots (Cecato et al., 2004). Therefore, it is important to understand how nutrient availability interferes in the root growth and morphology because there is greater root density in spots with higher nutrient availability (Marschner, 1995).

Root dry mass alone is not a good index to evaluate growth and nutrition of plants because thick and old roots contribute more to dry mass than to water and nutrient absorption (Mengel \& Kirkby, 2001). To better evaluate the grass growth it is necessary to consider root length and root surface (Zonta et al., 2006).

Nitrogen is a modulator of the plant development and stimulates root growth (Garnett et al., 2009). Batista \& Monteiro (2006) tested the influence of nitrogen and sulfur rates in nutrient solution on the Marandu palisadegrass development, and observed that high nitrogen rates increased root growth. Not much is known on the influence of magnesium on root growth of marandu palisadegrass. Monteiro \& Consolmagno Neto (2008) observed increase in root growth in high rates of potassium and magnesium. Magnesium is a macronutrient not only related to photosynthesis but also to plant enzymatic activity, and its effect is strongly influenced by nitrogen availability (Epstein \& Bloom, 2005).

The objective of this research was to evaluate the effect of nitrogen and magnesium availability on the root development of Marandu palisadegrass by quantification 
of dry mass, total and specific length, total and specific surface, and concentrations of nitrogen $(\mathrm{N})$, magnesium $(\mathrm{Mg})$, calcium $(\mathrm{Ca})$ and potassium $(\mathrm{K})$ in the roots of this forage grass.

\section{Material and Methods}

The study was carried out in a greenhouse, in Piracicaba, São Paulo State, Brazil. Brachiaria brizantha Stapf. cv. Marandu was grown in 3.6-L plastic pots filled with ground quartz as substrate. Quartz grains were washed with tap water and then with deionized water, before their use.

Grass seeds were sown in plastic trays irrigated with deionized water and after 15 days, 15 seedlings at approximately $5 \mathrm{~cm}$ of height were transplanted to each pot. Sequential thinnings were done until there was five plants per pot. During the first five days after transplant, plants were fed with nutrient solution diluted to $20 \%$ from the proposed concentrations of $\mathrm{N}$ and $\mathrm{Mg}$. Solutions were passed through the substrate three times per day, drained at the end of the day to $1 \mathrm{~L}$ bottles and the volume completed with deionized water. Solutions were completely renewed every 14 days.

Five $\mathrm{N}$ rates $\left(2 ; 9 ; 16 ; 23\right.$ and $\left.30 \mathrm{mmol} \mathrm{L}^{-1}\right)$ and five $\mathrm{Mg}$ rates $\left(0.05 ; 0.70 ; 1.35 ; 2.00\right.$ and $\left.2.65 \mathrm{mmol} \mathrm{L}^{-1}\right)$ were studied in a fractionated factorial $5^{2}$, according to Littell \& Mott (1975), resulting in 13 combinations: $2 / 0.05 ; 2 / 1.35 ; 2 / 2.65$; 9/0.70; 9/2.00; 16/0.05; 16/1.35; 16/2.65; 23/0.70; 23/2.00; $30 / 0.05 ; 30 / 1.35$ e $30 / 2.65$. The experimental design was a randomized block, with four replications.

The nutrient solution was made according to Hoagland \& Arnon (1950), adjusted to studied rates of $\mathrm{N}$ and $\mathrm{Mg}$ (Table 1). Considering the results reported by Abreu (1994), Monteiro et al. (1995) and Santos (2003), it was used the ratio $70 \%: 30 \%$ nitrate:ammonium to achieve the $\mathrm{N}$ target rates. The concentration of $\mathrm{K}$ in the nutrient solutions was $8 \mathrm{mmol} \mathrm{L}^{-1}$ as recommended by Mattos et al. (2002) and Consolmagno Neto et al. (2007).

Grass plant growth was analyzed during two periods. The first period was from transplant to day 35, when the first harvest of above ground plants was done. The second growing period started after the first harvest to 28 days after that (day 63), when the second harvest was done. After the second harvest, grass root system was obtained by washing it from the substrate by using two sieves $(0.25 \mathrm{~mm}$ and $1 \mathrm{~mm})$ and tap and deionized water.

According to the method described by Rossielo et al. (1995), approximately $20 \%$ of root volume was separeted. This root material was placed in plastic boxes filled with deionized water and stained with Gentian violet $50 \mathrm{~g} \mathrm{~L}^{-1}$, during 24 hours . After that, roots were spread on a transparent plastic sheet and scanned. Scans were analyzed using SIARCS software (Portuguese acronym for Integrated System for Root and Soil Cover Analysis) Version 3.0, to estimate root length and surface (Crestana et al., 1994). Dry weight of scanned roots was used to calculate the specific length and specific area of roots in each experimental unit.

All roots (scanned and not scanned) were weighed after dried at $70^{\circ} \mathrm{C}$, ground in Wiley mill and stored in plastic bags. After sulfuric digestion, $\mathrm{N}$ concentration was determined by titration. Nitric-percloric digestion was followed by determinations of $\mathrm{Ca}$ and $\mathrm{Mg}$ by atomic absorption spectrometry and $\mathrm{K}$ by flame photometry (Sarruge \& Haag, 1974).

Statistical analysis was done by using the SAS software (SAS, 2000). The F test was performed and polynomial regression analysis (response surface) was calculated by using the RSREG function in cases where interaction of $\mathrm{N} \times \mathrm{Mg}$ was significant. In cases where $\mathrm{N} \times \mathrm{Mg}$ interaction was not significant, regression analysis models of first and second degrees were performed for individual rates of nutrients, using the GLM function. A threshold of 5\% significance was adopted in all cases.

\section{Results and Discussion}

The interaction of $\mathrm{N} \times \mathrm{Mg}$ was not significant for root dry mass production of Marandu palisadegrass (Figure 1). The combination of $30 \mathrm{mmol} \mathrm{L}^{-1}$ of $\mathrm{N}$ with $2.40 \mathrm{mmol} \mathrm{L}^{-1}$ of $\mathrm{Mg}$ resulted in maximum root dry mass. Use of high rates of a single nutrient ( $30 \mathrm{mmol} \mathrm{L}^{-1}$ of $\mathrm{N}$ or $2.65 \mathrm{mmol} \mathrm{L}^{-1}$ of $\mathrm{Mg}$ ) was not sufficient to maximize root dry mass. On the other hand, even with intermediary rates of nutrients, such as $16 \mathrm{mmol} \mathrm{L}^{-1}$ of $\mathrm{N}$ and $1.35 \mathrm{mmol} \mathrm{L}^{-1}$ of $\mathrm{Mg}$, root dry mass reached $80 \%$ of maximum production. Batista $\&$ Monteiro (2006) studied $\mathrm{N}$ rates (1; 9; 15; 24 and $\left.33 \mathrm{mmol} \mathrm{L}^{-1}\right)$ combined with $\mathrm{S}$ rates $(0.1 ; 0.4 ; 1 ; 2$ and $2.5 \mathrm{mmol} \mathrm{L}^{-1}$ ) in the nutrition of Marandu palisadegrass and observed a positive effect of $\mathrm{N}$ in root dry mass production, but the combinations with $\mathrm{S}$ did not result in the maximum root dry mass production.

Corrêa (1996) studied three $\mathrm{N}$ rates (3, 15 and $27 \mathrm{mmol} \mathrm{L}^{-1}$ ) combined with two $\mathrm{Mg}$ rates (0.2 and $2 \mathrm{mmol} \mathrm{L}^{-1}$ ) in the root dry mass production of three cultivars of Panicum maximum and observed significant effect of Mg in the root dry mass production only when high rates of $\mathrm{N}$ was also used. In the present experiment, there was no response to $\mathrm{Mg}$ rates when coupled with low rates of N (Figure 1). 
Monteiro \& Consolmagno Neto (2008) worked with Panicum maximum cv. Tanzania (Tanzania guineagrass) to evaluate combinations of $\mathrm{K}$ rates with $\mathrm{Mg}$ rates, in the presence of $21 \mathrm{mmol} \mathrm{L}^{-1}$ of $\mathrm{N}$. They observed that the combination $8.4 \mathrm{mmol} \mathrm{L}^{-1}$ of $\mathrm{K}$ with $1.9 \mathrm{mmol} \mathrm{L}^{-1}$ of $\mathrm{Mg}$ resulted in maximum root dry mass. However, in the present study (Figure 1), such combination of rates did not allow Marandu palisadegrass to achieve the maximum root dry mass, being necessary higher rates of $\mathrm{Mg}$, and mostly, of $\mathrm{N}$. The N rate used by Monteiro \& Consolmagno Neto (2008) might not be sufficient to allow maximum dry root production for Tanzania guineagrass.

The interaction $\mathrm{N}$ rates $\times \mathrm{Mg}$ rates was significant for root length (Figure 2). The combinations of higher rates of $\mathrm{N}$ and $\mathrm{Mg}$ was not sufficient to achieve the maximum root length of Marandu palisadegrass (Figure 2), but the root length in the higher rates was five times greater than in the lower rates.

Lavres Junior \& Monteiro (2003) studied Panicum maximum cv. Mombaça under combinations of $\mathrm{N}$ and $\mathrm{K}$ rates and observed that $\mathrm{N}$ was the main nutrient controlling root length, although the highest $\mathrm{N}$ rate $\left(33 \mathrm{mmol} \mathrm{L}^{-1}\right.$ ) was not enough to maximize the root length. Monteiro \& Consolmagno Neto (2008) concluded that the root length of Tanzania guineagrass was maximum only with the high $\mathrm{K}$ rate of $10.9 \mathrm{mmol} \mathrm{L}^{-1}$ combined with the high rate of $\mathrm{Mg}\left(2.3 \mathrm{mmol} \mathrm{L}^{-1}\right)$, and the $\mathrm{N}$ rate of $21 \mathrm{mmol} \mathrm{L}^{-1}$. Therefore, the lack of a high rate of $\mathrm{N}$, such as $21 \mathrm{mmol} \mathrm{L}^{-1}$, could be limiting to the development of the root system. Lavres Junior \& Monteiro (2003), also studying Panicum maximum, did not observed the maximum root length, demonstrating the need of $\mathrm{N}$ rates even higher than $21 \mathrm{mmol} \mathrm{L}^{-1}$ to obtain the maximum root length.

The interaction $\mathrm{N} \times \mathrm{Mg}$ was significant for root surface (Figure 3). Rates were not sufficient to obtain the maximum root surface, and low rates of $\mathrm{N}$ and $\mathrm{Mg}$ resulted in small root surface as compared to high rates of these nutrients. Such results agree with those reported by Batista \& Monteiro (2006) in a study with rates of $\mathrm{N}$ and $\mathrm{S}$ on Marandu palisadegrass, and also found that low rates of $\mathrm{N}$ implied small root surface as compared to high rates, as well as the results of $\mathrm{Mg}$ and $\mathrm{K}$ rates on Tanzania guineagrass reported by Monteiro \& Consolmagno Neto (2008) in which low rates of $\mathrm{Mg}$ resulted in small root surface.

The $\mathrm{N}$ rates $\times \mathrm{Mg}$ rates interaction was not significant for specific root length of Marandu palisadegrass, although isolated effects were noted for $\mathrm{N}$ and $\mathrm{Mg}$ rates (Figures $4 \mathrm{a}$ and $4 \mathrm{~b}$ ). Low rates of $\mathrm{N}$ and $\mathrm{Mg}$ resulted in higher specific length of Marandu palisadegrass roots, as compared to high rates. The minimum points of specific root length were reached at rates $17.7 \mathrm{mmol} \mathrm{L}^{-1}$ of $\mathrm{N}$ and $1.7 \mathrm{mmol} \mathrm{L}^{-1}$ of $\mathrm{Mg}$.

At low nutrient availability, plants grow thin roots, increasing the specific length and decreasing the dry mass and volume of roots (Fitter, 1999; Lavres Junior \& Monteiro, 2003). However, it was observed that at the $\mathrm{N}$ rate of $30 \mathrm{mmol} \mathrm{L}^{-1}$ (Figure 4a) there was an increase of fine roots as compared to the $16 \mathrm{mmol} \mathrm{L}^{-1}$ rates. Such behavior was not observed for the highest $\mathrm{Mg}$ rate when compared to the $1.35 \mathrm{mmol} \mathrm{L}^{-1} \mathrm{Mg}$ rate (Figure 4b). In this case, it is known that the new portions of the root system have greater capacity of nutrient absorption, due to the greater influx of nutrient and to the greater absorption surfaces available as compared to older roots that developed bark (Zonta et al., 2006). The increase in $\mathrm{N}$ rates from $16 \mathrm{mmol} \mathrm{L}^{-1}$ to $30 \mathrm{mmol} \mathrm{L}^{-1}$ resulted in growth of new root structures to absorb the nutrient.

Following the trend of specific root length, the specific surface of roots of Marandu palisadegrass had significant effect of $\mathrm{N}$ and $\mathrm{Mg}$ rates independently (Figures 4c e 4d). The highest $\mathrm{N}$ rate resulted in specific root surface greater

Table 1 - Stock solution volumes employed in preparation of nitrogen and magnesium nutrient solutions

\begin{tabular}{|c|c|c|c|c|c|c|c|c|c|c|c|c|c|}
\hline $\begin{array}{l}\text { Nitrogen }\left(\mathrm{mmol} \mathrm{L}^{-1}\right) \\
\text { Magnesium }\left(\mathrm{mmol} \mathrm{L}^{-1}\right)\end{array}$ & $\begin{array}{c}2 \\
0.05\end{array}$ & $\begin{array}{c}2 \\
1.35\end{array}$ & $\begin{array}{c}2 \\
2.65\end{array}$ & $\begin{array}{c}9 \\
0.7\end{array}$ & $\begin{array}{l}9 \\
2\end{array}$ & $\begin{array}{c}16 \\
0.05\end{array}$ & $\begin{array}{c}16 \\
1.35\end{array}$ & $\begin{array}{c}16 \\
2.65\end{array}$ & $\begin{array}{l}23 \\
0.7\end{array}$ & $\begin{array}{c}23 \\
2\end{array}$ & $\begin{array}{c}30 \\
0.05\end{array}$ & $\begin{array}{c}30 \\
1.35\end{array}$ & $\begin{array}{c}30 \\
2.65\end{array}$ \\
\hline Stock solution & \multicolumn{13}{|c|}{ Volume $\left(\mathrm{mL} \mathrm{L}^{-1}\right)$} \\
\hline $\mathrm{KH}_{2} \mathrm{PO}_{4}\left(1 \mathrm{~mol} \mathrm{~L}^{-1}\right)$ & 1 & 1 & 1 & 1 & 1 & 1 & 1 & 1 & 1 & 1 & 1 & 1 & 1 \\
\hline $\mathrm{MgCl}_{2}\left(1 \mathrm{~mol} \mathrm{~L}^{-1}\right)$ & 0.05 & 1.35 & 2.65 & 0.7 & 2 & 0.05 & 1.35 & 2.65 & 0.7 & 2 & 0.05 & 1.35 & 2.65 \\
\hline $\mathrm{KNO}_{3}\left(1 \mathrm{~mol} \mathrm{~L}^{-1}\right)$ & 0.8 & 0.8 & 0.8 & 3.6 & 3.6 & 6.4 & 6.4 & 6.4 & 7 & 7 & 7 & 7 & 7 \\
\hline $\mathrm{NH}_{4} \mathrm{NO}_{3}\left(1 \mathrm{~mol} \mathrm{~L}^{-1}\right)$ & 0.6 & 0.6 & 0.6 & 2.7 & 2.7 & 4.8 & 4.8 & 4.8 & 6.9 & 6.9 & 9 & 9 & 9 \\
\hline $\mathrm{Ca}\left(\mathrm{NO}_{3}\right)_{2}\left(1 \mathrm{~mol} \mathrm{~L}^{-1}\right)$ & - & - & - & - & - & - & - & - & 1.1 & 1.1 & 2.5 & 2.5 & 2.5 \\
\hline $\mathrm{CaSO}_{4} \cdot 2 \mathrm{H}_{2} \mathrm{O}\left(0,01 \mathrm{~mol} \mathrm{~L}^{-1}\right)$ & 200 & 200 & 200 & 200 & 200 & 200 & 200 & 200 & 200 & 200 & 200 & 200 & 200 \\
\hline $\mathrm{CaCl}_{2}^{4}\left(1 \mathrm{~mol} \mathrm{~L}^{-1}\right)$ & 3 & 3 & 3 & 3 & 3 & 3 & 3 & 3 & 1.9 & 1.9 & 0.5 & 0.5 & 0.5 \\
\hline $\mathrm{KCl}\left(1 \mathrm{~mol} \mathrm{~L}^{-1}\right)$ & 6.2 & 6.2 & 6.2 & 3.4 & 3.4 & 0.6 & 0.6 & 0.6 & - & - & - & - & - \\
\hline Micronutrients* & 1 & 1 & 1 & 1 & 1 & 1 & 1 & 1 & 1 & 1 & 1 & 1 & 1 \\
\hline $\mathrm{Fe}-\mathrm{EDTA}^{* *}$ & 1 & 1 & 1 & 1 & 1 & 1 & 1 & 1 & 1 & 1 & 1 & 1 & 1 \\
\hline
\end{tabular}

* Composition of micronutrient stock solution $\left(\mathrm{g} \mathrm{L}^{-1}\right): \mathrm{H}_{3} \mathrm{BO}_{3}=2.86 ; \mathrm{MnCl}_{2} \cdot 4 \mathrm{H}_{2} \mathrm{O}=1.81, \mathrm{ZnCl}_{2}=0.10, \mathrm{CuCl}_{2}=0.10$ and $\mathrm{H}_{2} \mathrm{MoO}_{4} \cdot 4 \mathrm{H}_{2} \mathrm{O}=0.02$.

** Disodium EDTA (26.1 g) was dissolved in $286 \mathrm{~mL}$ of $\mathrm{NaOH} 1 \mathrm{~mol} \mathrm{~L}^{-1}$, added $24.0 \mathrm{~g} \mathrm{FeSO} \cdot 7 \mathrm{H}_{2} \mathrm{O}$ and the solution was aired for overnight and had its volume completed to $1 \mathrm{~L}$ with deionized water. 
than the $16 \mathrm{mmol} \mathrm{L}^{-1}$ due to the growth of new roots. Rates of Mg higher than $0.7 \mathrm{mmol} \mathrm{L}^{-1}$ did not result in significant difference as compared to the $0.05 \mathrm{mmol} \mathrm{L}^{-1}$ rate.

The nutrient supply may change the root growth and morphology, according to Marschner (1995). Plants in a low nutrient availability environment put most of their dry mass in growing roots (Hill et al., 2006), resulting in a different morphology for the root system. Changes in morphology both in the root system and in the above ground plant morphology are common in plants under nutrient stress (Schippers \& Olff, 2000).

The $\mathrm{N}$ rates $\times \mathrm{Mg}$ rates interaction was significant for $\mathrm{N}$ concentration in Marandu palisadegrass roots (Figure 5). The highest $\mathrm{N}$ concentration in the roots was achieved at the highest $\mathrm{N}$ rate and the lowest $\mathrm{Mg}$ rate. Combination of high rates of $\mathrm{N}$ and $\mathrm{Mg}$ resulted in lower $\mathrm{N}$ concentration in roots than combinations of high $\mathrm{N}$ rates with low $\mathrm{Mg}$ rates. That demonstrates the importance of $\mathrm{Mg}$ for the $\mathrm{N}$ absorption and metabolism, being the $\mathrm{N}$ used for production of root mass instead of being stored in this plant tissue. Therefore, variation in $\mathrm{N}$ root concentration from 4 to $24 \mathrm{~g} \mathrm{~kg}^{-1}$ was observed, being the highest values observed in the low $\mathrm{Mg}$ rates.

In situations in which Mg deficiency in grass plant and high $\mathrm{N}$ rates in solution occurs, $\mathrm{N}$ absorption may be limited to avoid the synthesis of Reactive Oxygen Species (ROS) in both roots and above ground tissues of the plant. According to Medici et al. (2004), plants have several mechanisms to avoid ROS production, such as preventing $\mathrm{N}$ excess and the use of anti oxidant enzymes.

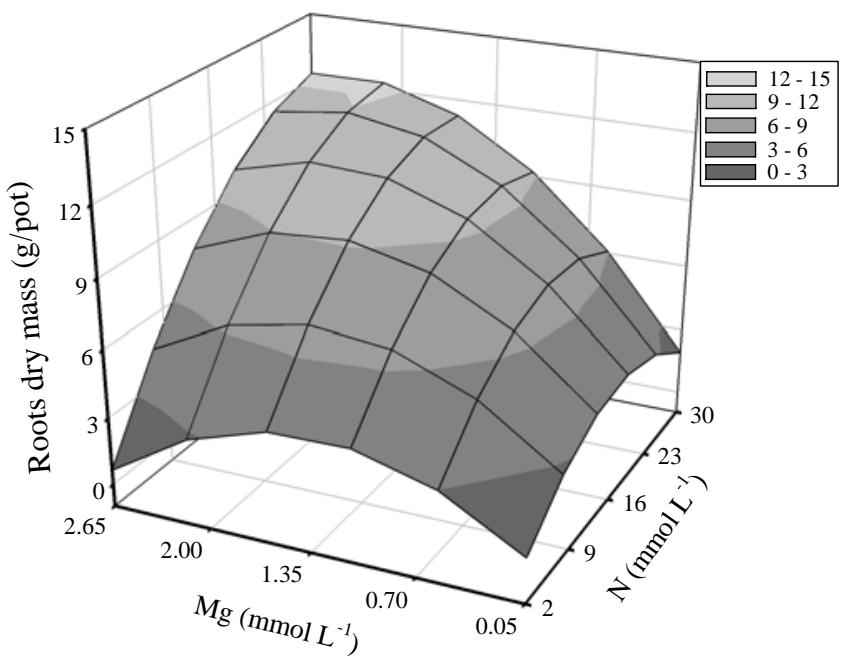

$$
\begin{gathered}
\mathrm{Y}=-0.046+0.426 \mathrm{~N}-0.013 \mathrm{~N}^{2}+4.786 \mathrm{Mg}-1.931 \mathrm{Mg}^{2}+0.147 \mathrm{MgN} \\
\mathrm{R}^{2}=0.83 * *
\end{gathered}
$$

Figure 1 - Roots dry mass of Marandu palisadegrass with nitrogen and magnesium rates combined in nutrient solution.
Manarin \& Monteiro (2002) evaluated the growth of Mombaça guineagrass and observed that the increase in $\mathrm{N}$ rates resulted in linear increase in $\mathrm{N}$ concentration in roots, highlighting the ability of plants to store $\mathrm{N}$ in roots, which is a result of the balance between the $\mathrm{N}$ concentration in above ground plant and concentration in roots (Overman \& Scholtz, 2003).

In the present study, availability of high rates of $\mathrm{N}$ in solution resulted in greater absorption of $\mathrm{N}$ as compared to low availability. Greater $\mathrm{N}$ availability resulted in leaves, stalks, sheaths and roots nutrient storage (Lavres Junior \& Monteiro, 2006), always keeping the balance inside grass cells.

The concentration of $\mathrm{Mg}$ in roots changed linearly and positively with the $\mathrm{Mg}$ rates supplied to the grass (Figure 6). Monteiro \& Consolmagno Neto (2008) also observed the linear effect of $\mathrm{Mg}$ rates in the $\mathrm{Mg}$ concentration in Tanzania guineagrass roots. The increase in $\mathrm{Mg}$ concentration in roots caused an imbalance among the cations (Mengel \& Kirkby, 2001), resulting in decreases of $\mathrm{Ca}$ and $\mathrm{K}$ concentrations in the plant (Monteiro \& Consolmagno Neto, 2008).

The interaction $\mathrm{N}$ rates $\times \mathrm{Mg}$ rates was not significant for the Ca concentration in roots. Increase in $\mathrm{N}$ availability resulted in linear increase of Ca concentration in roots (Figure 7a), reaching approximately $3 \mathrm{~g} \mathrm{~kg}^{-1}$, while the variation in the $\mathrm{Mg}$ supply resulted in linear decrease in the Ca concentration in roots (Figure 7b), reaching values lower than $1.6 \mathrm{~g} \mathrm{~kg}^{-1}$.

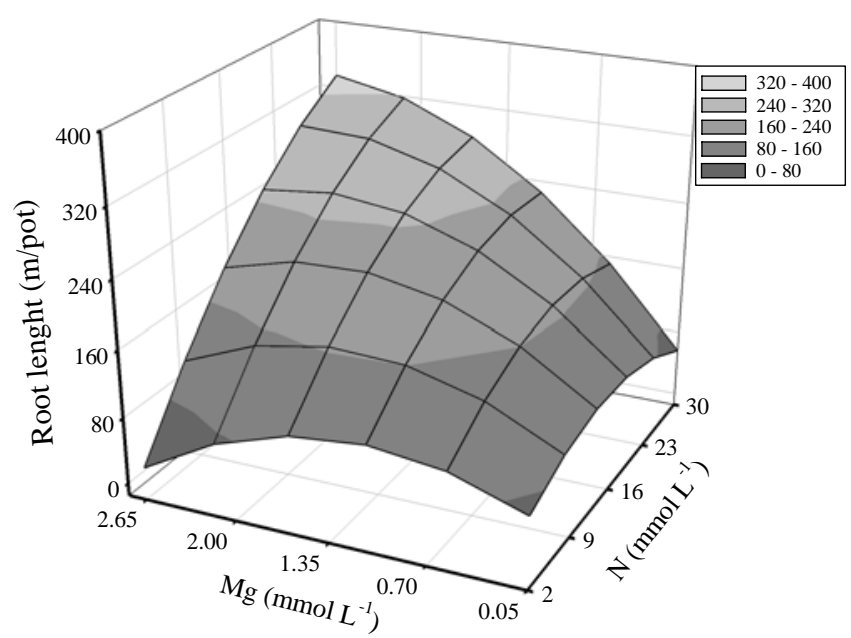

$$
\begin{gathered}
\mathrm{Y}=56.163+5.973 \mathrm{~N}-0.210 \mathrm{~N}^{2}+70.434 \mathrm{Mg}-36.052 \mathrm{Mg}^{2}+4.246 \mathrm{MgN} \\
\mathrm{R}^{2}=0.75^{* *}
\end{gathered}
$$

Figure 2 - Root length of Marandu palisadegrass with nitrogen and magnesium rates combined in nutrient solution. 


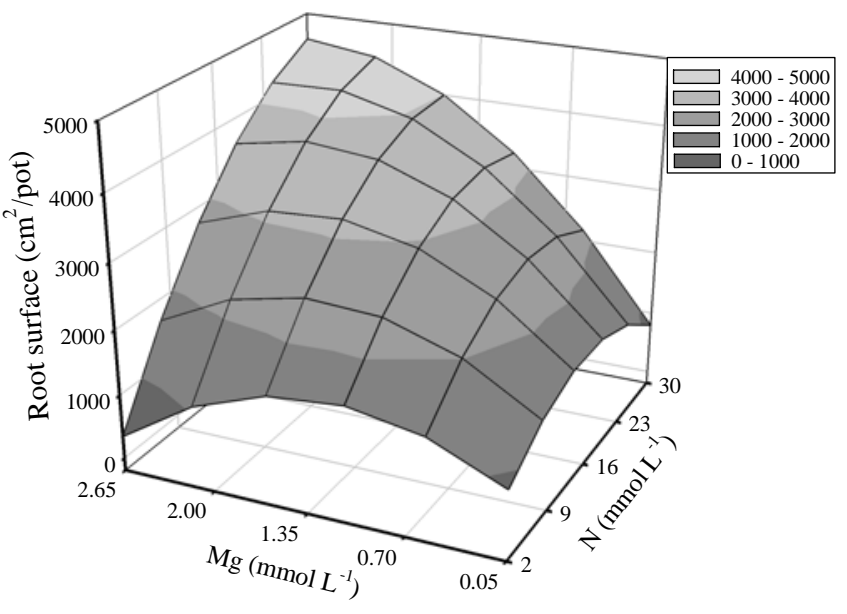

$\mathrm{Y}=602.545+113.958 \mathrm{~N}-3.751 \mathrm{~N}^{2}+1209.904 \mathrm{Mg}-568.638 \mathrm{Mg}^{2}+59.651 \mathrm{MgN}$ $\mathrm{R}^{2}=0.78^{* *}$

Figure 3 - Root surface of Marandu palisadegrass with nitrogen and magnesium rates combined in nutrient solution.
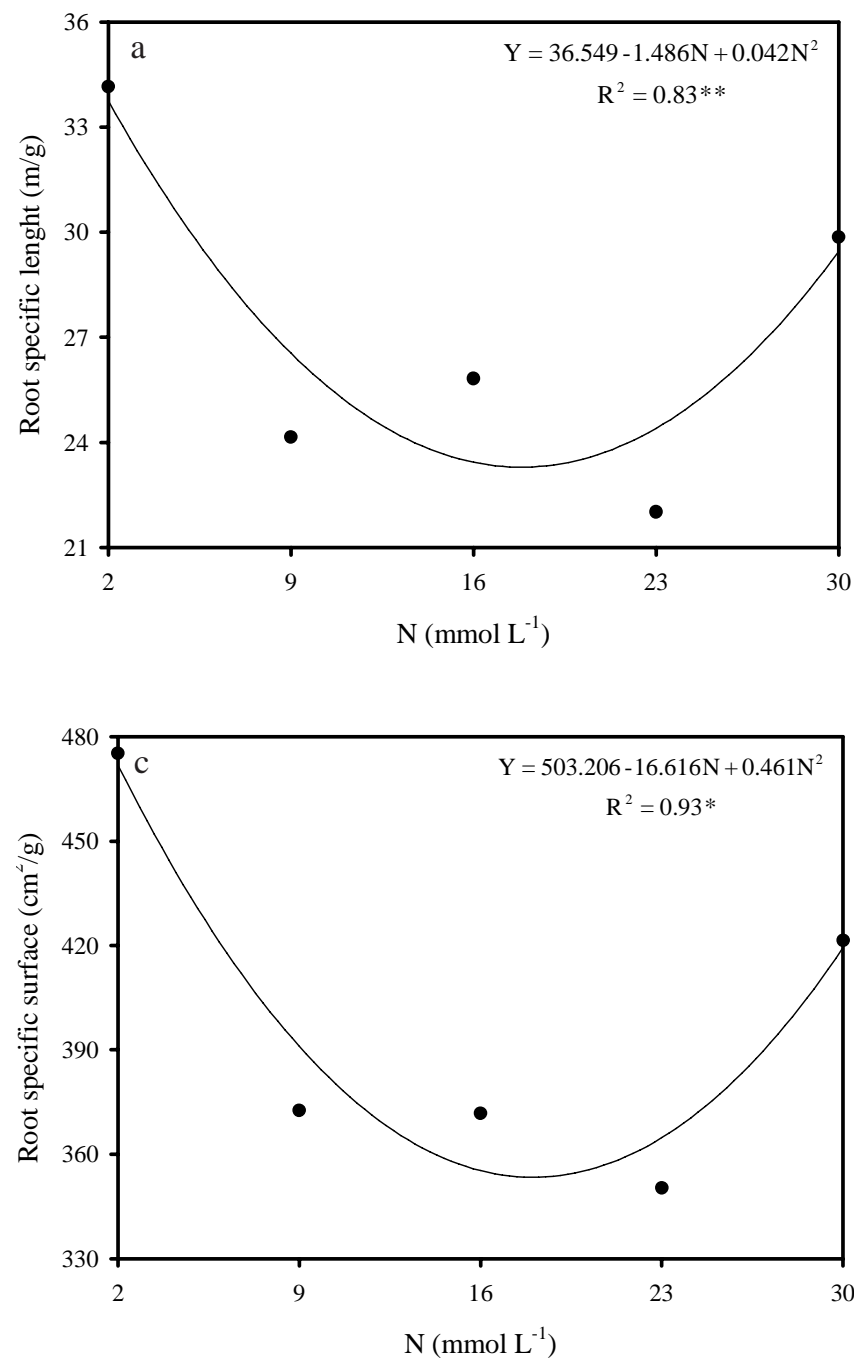

Calcium is used in new cell walls synthesis, being allocated particularly in the cell plate (Taiz \& Zeiger, 2009). Increase in the $\mathrm{N}$ rates (Figure $7 \mathrm{a}$ ) may increase the need of Ca to grow and to reinforce cell walls, to activate enzymes and to balance the cations for the plant development (Epstein \& Bloom, 2005). However, Silveira \& Monteiro (2011) observed that the increase in N rates in Tanzânia guineagrass did not increase Ca absorption.

The increase in Ca concentration in Marandu palisadegrass roots as a function of $\mathrm{N}$ rates may be related to specific functions of this grass that still need to be clarified. In a result similar to the one found in the present study, Monteiro et al. (1995) reported that Marandu palisadegrass grew with $5 \mathrm{mmol} \mathrm{L}^{-1}$ of $\mathrm{Ca}$, and the remaining nutrients in adequate concentrations, Ca concentration in roots was ranged from 3 to $4.6 \mathrm{~g} \mathrm{~kg}^{-1}$, raising the suspicion of a great capacity of Marandu palisadegrass
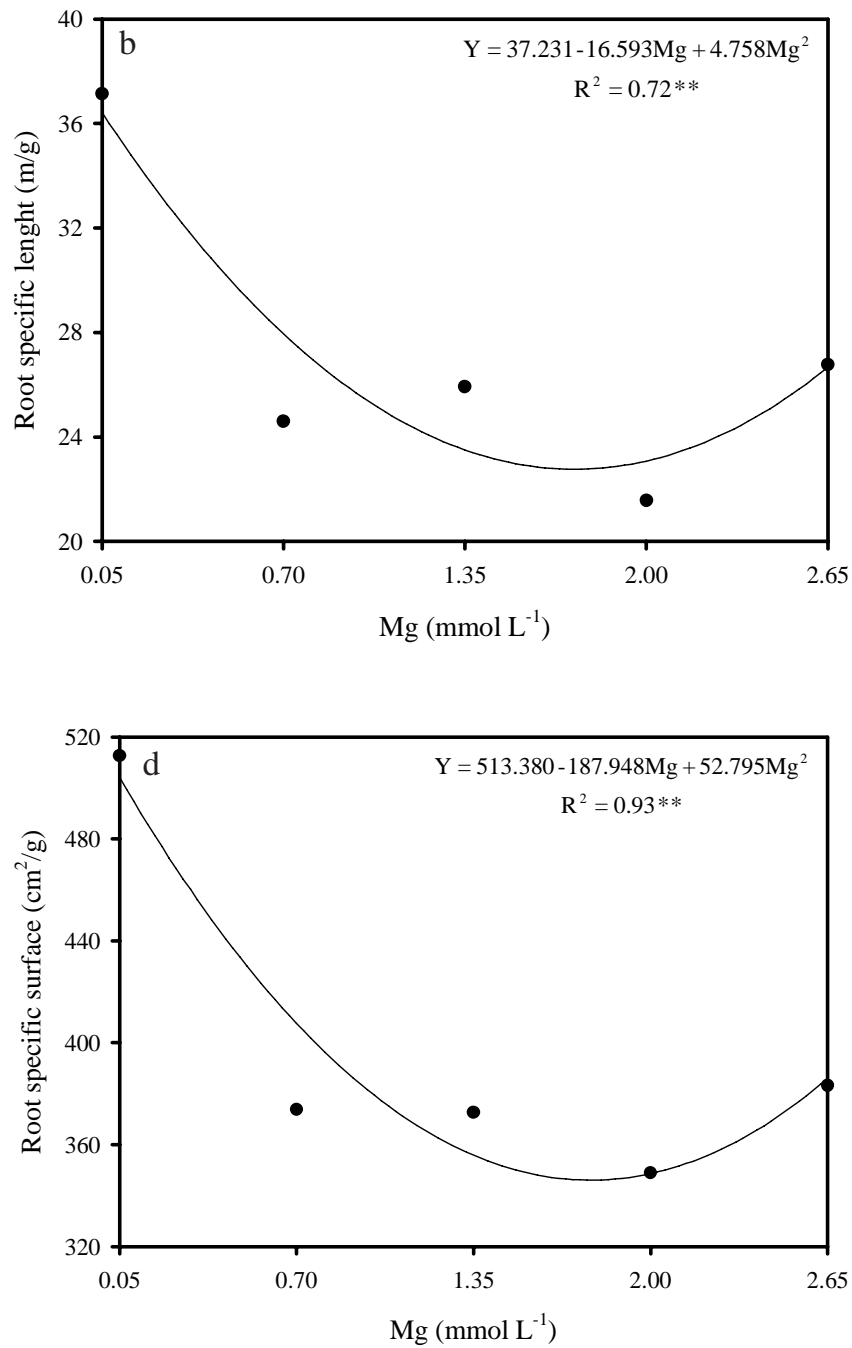

Figure 4 - Root specific length and surface of Marandu palisadegrass with nitrogen rates (a, c) and magnesium rates (b, d) in nutrient solution. 


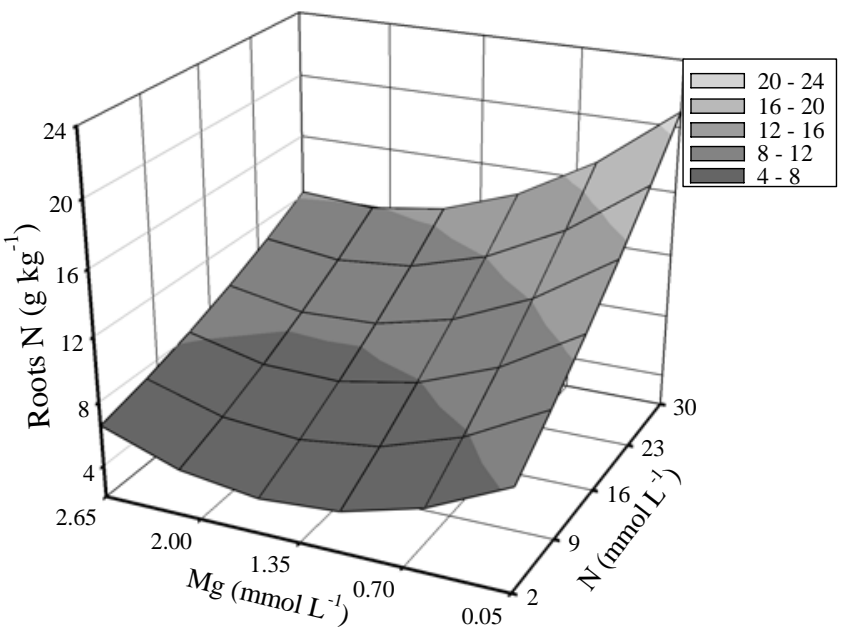

$\mathrm{Y}=7.9216+0.3597 \mathrm{~N}+0.0029 \mathrm{~N}^{2}-5.6524 \mathrm{Mg}+1.9048 \mathrm{Mg}^{2}-0.0946 \mathrm{MgN}$ $\mathrm{R}^{2}=0.82 * *$

Figure 5 - Nitrogen $(\mathrm{N})$ concentration in roots of Marandu palisadegrass with nitrogen and magnesium rates combined in nutrient solution.

to store Ca. In addition, Silveira \& Monteiro (2011) observed increase in root concentration of Ca up to $2.5 \mathrm{~g} \mathrm{~kg}^{-1}$ at the $5.5 \mathrm{mmol} \mathrm{L}^{-1}$.

The increase in $\mathrm{Mg}$ rates in solution decreased the Ca concentration in roots (Figure 7b). Because $\mathrm{Ca}$ and $\mathrm{Mg}$ antagonism, increasing $\mathrm{Mg}$ absorption implies decreases in Ca absorption. Total sum of cations in a plant varies very little (Mengel \& Kirkby, 2001), and a cation imbalance may impact plant metabolism.

The interaction $\mathrm{N}$ rates $\times \mathrm{Mg}$ rates was significant for $\mathrm{K}$ concentration in roots (Figure 8 ). Concentration of $\mathrm{K}$ in roots had minimum value at the highest $\mathrm{N}$ and $\mathrm{Mg}$ rates. Potassium concentration in roots was $6 \mathrm{~g} \mathrm{~kg}^{-1}$ at high $\mathrm{N}$ and $\mathrm{Mg}$ rates and $36 \mathrm{~g} \mathrm{~kg}^{-1}$ at the low $\mathrm{N}$ and $\mathrm{Mg}$ rates. Therefore, increase in availability of $\mathrm{N}$ and $\mathrm{Mg}$ resulted in decrease in $\mathrm{K}$ root concentration (Figure 8).

Plant requires large amount of $\mathrm{N}$ and $\mathrm{Mg}$ to maximum root growth. High $\mathrm{N}$ rates resulted in increase in root system and dilution of $\mathrm{K}$ root concentration, whereas high Mg rate depressed $\mathrm{K}$ concentration due to antagonism (Primavesi, 2006). Large concentration of $\mathrm{N}$ and $\mathrm{Mg}$ in nutrient solution with constant concentration of $\mathrm{K}$ may cause $\mathrm{K}$ deficiency in plants due to nutrient imbalance.

Absorption, translocation and assimilation of cations and anions by plants depend on nutrient concentration in solution and also on the presence of other cations and anions in solution (Marschner, 1995). The antagonism among Mg, Ca and $\mathrm{K}$ was also observed by Monteiro \& Consolmagno Neto (2008) in Tanzania guineagrass.

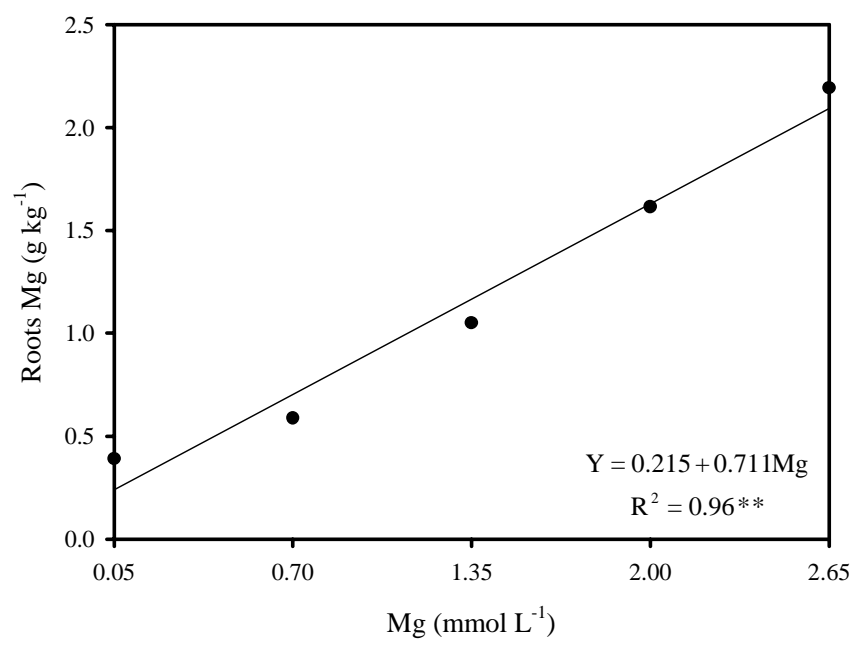

Figure 6 - Magnesium (Mg) concentration in roots of Marandu palisadegrass with magnesium rates in nutrient solution.
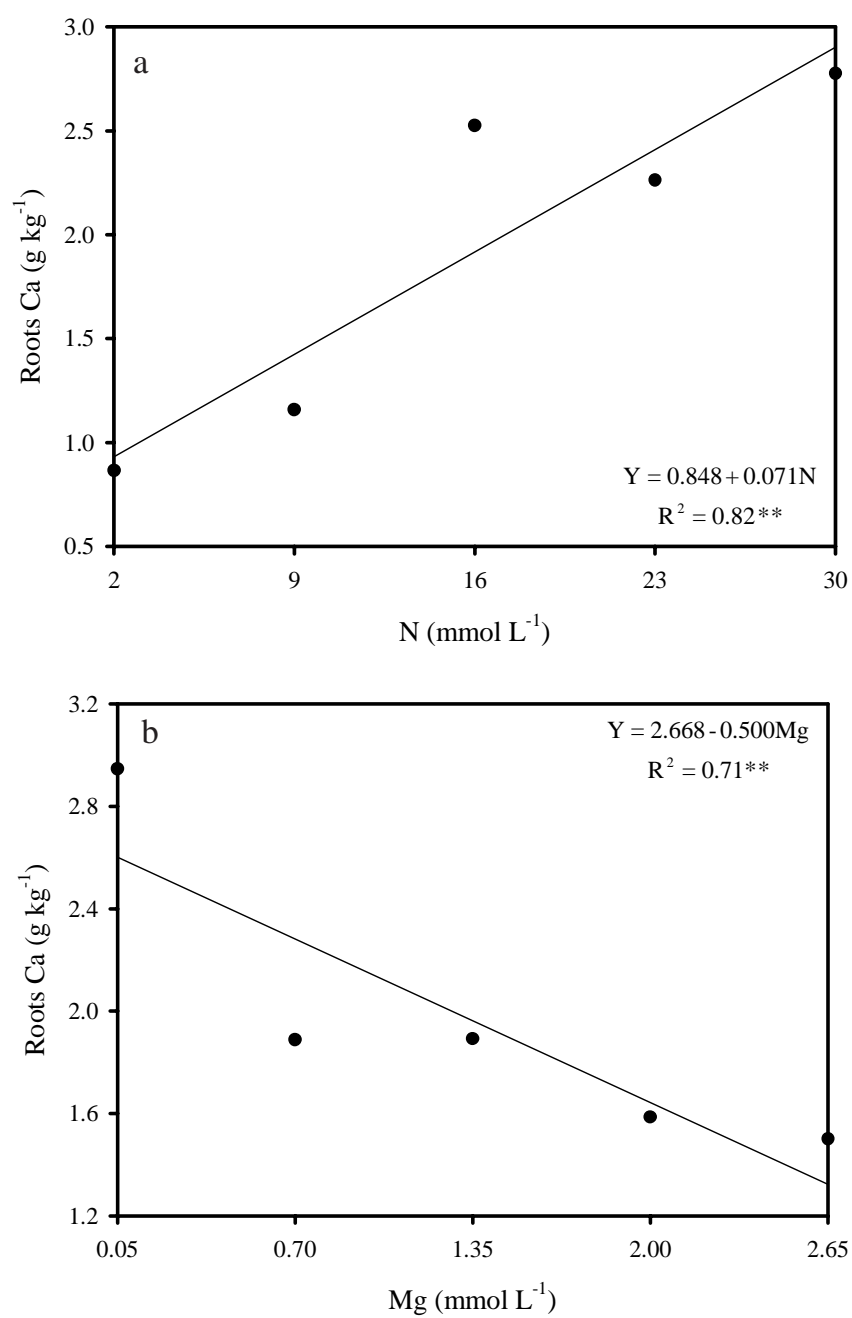

Figure 7 - Calcium (Ca) concentration in roots of Marandu Palisadegrass with nitrogen rates (a) and magnesium rates (b) in nutrient solution. 


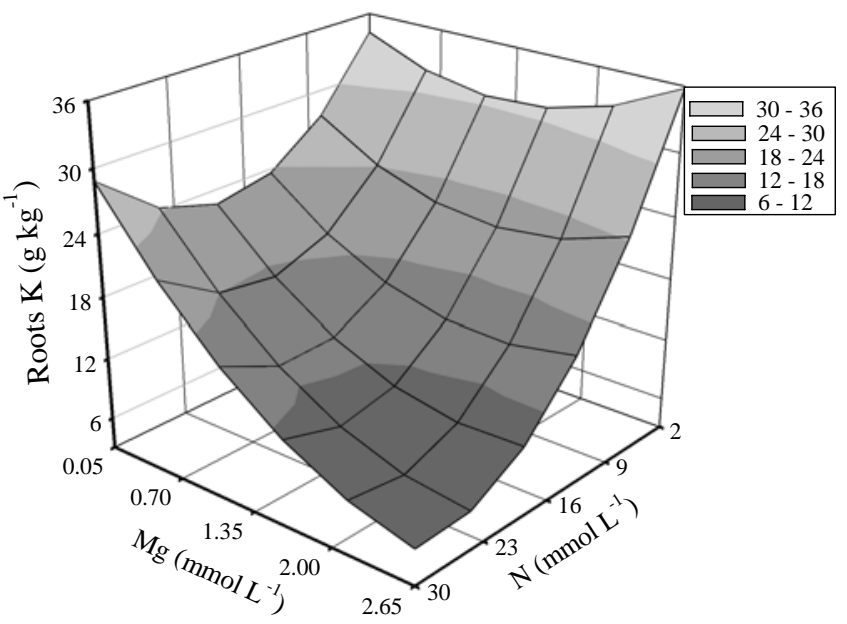

$\mathrm{Y}=37.4808-1.6034 \mathrm{~N}+0.0446 \mathrm{~N}^{2}-5.5191 \mathrm{Mg}+2.5237 \mathrm{Mg}^{2}-0.3294 \mathrm{MgN}$ $\mathrm{R}^{2}=0.76^{* *}$

Figure 8 - Potassium (K) concentration in roots of Marandu palisadegrass with nitrogen and magnesium rates combinations in nutrient solution.

\section{Conclusions}

Combination of high rates of $\mathrm{N}$ and $\mathrm{Mg}$ results in increase in root dry mass, root length and root surface of Marandu palisadegrass, but when not combined, high rates of $\mathrm{N}$ and $\mathrm{Mg}$ result in lower specific length and surface of roots. Combinations of high rates of $\mathrm{N}$ and $\mathrm{Mg}$ result in increase in $\mathrm{N}$ concentration and decrease in $\mathrm{K}$ concentration in roots. Calcium concentration in roots increases as $\mathrm{N}$ rates increase and decrease as $\mathrm{Mg}$ concentration increases. Greater Mg supply increases Mg concentration in roots of Marandu palisadegrass.

\section{References}

ABREU, J.B.R. Níveis de nitrogênio e proporções de nitrato e amônio afetando a produção, atividade da redutase do nitrato e composição de três gramíneas forrageiras. 1994. 109f. Dissertação (Mestrado em Solos e Nutrição de Plantas) - Escola Superior de Agricultura "Luiz de Queiroz", Universidade de São Paulo, Piracicaba.

BATISTA, K.; MONTEIRO, F.A. Sistema radicular do capimmarandu, considerando as combinações de doses de nitrogênio e enxofre. Revista Brasileira de Ciência do Solo, v.30, p.821-828, 2006.

CECATO, U.; JOBIM, C.C.; REGO, F.C.A. et al. Sistema radicular - componente esquecido das pastagens. In: SIMPÓSIO SOBRE MANEJO ESTRATÉGICO DA PASTAGEM, 2., 2004, Viçosa, MG. Anais... Viçosa, MG: Universidade Federal de Viçosa, 2004. p.159-207.

CENSO AGROPECUÁRIO. [2006]. In: IBGE. Brasil: Instituto Brasileiro de Geografia e Estatística, 2006. Disponível em: <http:// www.ibge.gov.br>. Acesso em: 13/08/2009.
CONSOLMAGNO NETO, D.; MONTEIRO, F.A.; DECHEN, A.R. Características produtivas do capim-tanzânia cultivado com combinações de potássio e de magnésio. Acta Scientiarum, v.29, p.459-467, 2007.

CORRÊA, B.D. Doses de nitrogênio e de magnésio afetando aspectos produtivos e bioquímicos dos capins Colonião, Tanzânia-1 e Vencedor. 1996. 76f. Dissertação (Mestrado em Solos e Nutrição de Plantas) - Escola Superior de Agricultura "Luiz de Queiroz", Universidade de São Paulo, Piracicaba.

CRESTANA, S.; GUIMARÃES, M.F.; JORGE, L.A.C. et al. Avaliação da distribuição de raízes no solo auxiliada por processamento de imagens digitais. Revista Brasileira de Ciência do Solo, v.18, p.365-371, 1994.

EPSTEIN, E.; BLOOM, A.J. Mineral nutrition of plants: principles and perspectives. Sunderland: Sinauer Associates, 2005. 400p.

FITTER, A.H. Root dynamics systems: the developmental ecology of roots and root systems. In: SCHOLES, J.D.; BARKER, M.G. (Eds.) Physiological plant ecology. Ketchum: M.C. Press, 1999. p.115-130.

GARNETT, T.; CONN, V.; KAISER, B.N. Root based approaches to improving nitrogen use efficiency in plants. Plant, Cell and Environment, v.32, p.1272-1283, 2009.

HILL, J.O., SIMPSON, R.J., MOORE, A.D. et al. Morphology and response of roots of pasture species to phosphorus and nitrogen nutrition. Plant and Soil, v.286, p.7-19, 2006.

HOAGLAND, D.; ARNON, D.I. The water culture method for growing plants without soil. California Agriculture Experimental Station, 1950. 32p. (Circular 347).

LAVRES JR.; MONTEIRO, F.A. Diagnose nutricional de nitrogênio no capim-aruana em condições controladas. Revista Brasileira de Ciência do Solo, v.30, p.829-837, 2006.

LAVRES JR.; MONTEIRO, F.A. Perfilhamento, área foliar e sistema radicular do capim-mombaça submetido a combinações de doses de nitrogênio e potássio. Revista Brasileira de Zootecnia, v.32, p.1068-1075, 2003.

LITTELL, R.C.; MOTT, G.O. Computer assisted design and analysis of response surface experiments in agronomy. Soil and Crop Society of Florida Proceedings, v.34, p.94-97, 1975.

MANARIN, C.A.; MONTEIRO, F.A. Nitrogênio na produção e diagnose foliar do capim-mombaça. Boletim de Indústria Animal, v.59, p.115-123, 2002.

MARSCHNER, H. Mineral nutrition of higher plants. 2.ed London: Academic Press, 1995. 889p.

MATTOS, W.T.; SANTOS, A.R.; ALMEIDA, A.A.S. et al. Aspectos produtivos e diagnose nutricional do capim-Tanzânia submetido a doses de potássio. Magistra, v.14, p.37-44, 2002.

MEDICI, L.O.; AZEVEDO, R.A.; SMITH, R.J. et al. The influence of nitrogen supply on antioxidant enzymes in plant roots. Functional Plant Biology, v.31, p.1-9, 2004.

MENGEL, K.; KIRKBY, E.A. Principles of plant nutrition. 5.ed. Dordrechth: Kluwer Academic Publishers, 2001. 849p.

MONTEIRO, F.A.; CONSOLMAGNO NETO, D. Sistema radicular do capim-tanzânia adubado com potássio e magnésio. Revista Brasileira de Zootecnia, v.37, p.810-818, 2008.

MONTEIRO, F.A.; RAMOS, A.K.B.; CARVALHO, D.D. et al. Cultivo de Brachiaria brizantha Stapf. cv. Marandu em solução nutritiva com omissões de macronutrientes. Scientia Agricola, v.52, p.135-141, 1995.

OVERMAN, A.R.; SCHOLTZ, R.V. Model analysis of forage response to split applications of nitrogen. II. Coupling of roots and tops. Communications in Soil Science and Plant Analysis, v.34, p.1539-1548, 2003.

PRIMAVESI, A.C.; PRIMAVESI, O.; CORRÊA, L.A. et al. Nutrientes na fitomassa de capim-Marandu em função de fontes e doses de nitrogênio. Revista Ciência e Agrotecnologia, v.30, p.562-568, 2006.

ROSSIELO, R.O.P.; ARAÚJO, A.P.; MANZATTO, C.V. et al. Comparação dos métodos fotoelétricos e da interação na 
determinação de área, comprimento e raio médio radicular. Pesquisa Agropecuária Brasileira, v.30, p.633-638, 1995. SANTOS, J.H.S. Proporção de nitrato e amônio na nutrição e produção dos capins Aruana e Marandu. 2003. 81f. Dissertação (Mestrado em Solos e Nutrição de Plantas) - Escola Superior de Agricultura “Luiz de Queiroz”, Universidade de São Paulo, Piracicaba.

SARRUGE, J.R.; HAAG, H.P. Análises químicas em plantas. Piracicaba: ESALQ, 1974. 56p.

SCHIPPERS, P.; OLFF, H. Biomass partitioning, architecture and turnover of six herbaceous species from habitats with different nutrient supply. Plant Ecology, v.149, p.219-231, 2000.
SILVEIRA, C.P.; MONTEIRO, F.A. Influência da adubação com nitrogênio e cálcio nas características morfológicas e produtivas das raízes de capim-tanzânia cultivado em solução nutritiva. Revista Brasileira de Zootecnia, v.40, p.47-52, 2011.

STATISTICAL ANALYSES SYSTEM - SAS. SAS/STAT. User's guide, version 8.0. Cary: SAS Institute, 2000.

TAIZ, L.; ZEIGER, E. Fisiologia vegetal. 4.ed. Porto Alegre: Artmed, 2009. 819p.

ZONTA, E.; BRASIL, F.C.; GOI, S.R. et al. O sistema radicular e suas interações com o ambiente edáfico. In: FERNANDES, M.S. (Ed.) Nutrição mineral de plantas. Viçosa, MG: Sociedade Brasileira de Ciência do Solo, 2006. p.7-52. 